\title{
Culture Shock, Adaptation, and Self-Concept of Tourism Human Resources in Welcoming the New Normal Era
}

\author{
Diana Simanjuntak 1,*(D) and Rina Fitriana 2 (D) \\ 1 Department of Hospitality, Sekolah Tinggi Ilmu Ekonomi Pariwisata YAPARI, \\ 40152, Bandung, East Java Province, Indonesia \\ 2 Department of Hospitality, Politeknik Sahid, 10220, Jakarta, Indonesia \\ * Corresponding Author: simanjuntak_dn@yahoo.com
}

\begin{abstract}
ARTICLE INFO
\section{Publication Info:}

Research Article

How to cite:

Simanjuntak, D., E Fitriana, R. (2020). Culture Shock, Adaptation, and Self-Concept of Tourism Human Resources in Welcoming the New Normal Era. Society, 8(2), 403-418.
\end{abstract}

DOI: $10.33019 /$ society.v8i2.200

Copyright (C) 2020. Owned by Author(s), published by Society

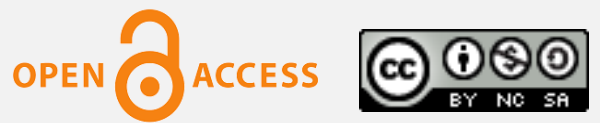

This is an open-access article.

License: Attribution-

NonCommercial-ShareAlike (CC BY-NC-SA)

Received: June 15, 2020;

Accepted: August 18, 2020;

Published: September 30, 2020;

\begin{abstract}
As a business that relies on human mobility, the tourism sector has proven to be severely affected by the Coronavirus disease (COVID-19) pandemic. The paralysis of tourism both nationally and globally as a result of the lockdown policy in various countries and the Large-Scale Social Restriction (LSSR) policy in Indonesia affects the operations of tourism businesses. This has raised high anxiety for Tourism Human Resources about the future of the tourism business. This research discusses culture shock, adaptation, and self-concept of Tourism Human Resources in welcoming the new normal era from a communication perspective, both related to intercultural communication, interpersonal communication, and selfconcept as part of communication psychology. This research used a qualitative research method with a case study approach. Data collection techniques were conducted through interviews, field observations, and document study through WhatsApp messages in several professional association groups, webinars, and mass media. The key informants in the research were 14 people as primary data and more than 200 members of the WhatsApp group "Housekeepers Jabar" as secondary data. The results of this research showed that Tourism Human Resources suffered from a culture shock and reached its lowest point in March to mid-April, but rose slowly from late April to June. There are three very stressful aspects of their life, consisting of cultural, social, and economic aspects. Cultural and social aspects are relatively easier to overcome, but the economic aspects are the most impactful because it concerns the sustainability of their life and their families. The period of awareness in the adaptation process is a period of struggle,
\end{abstract}

Copyright (C) 2020. Owned by Author(s), published by Society. This is an open-access article under the CC-BY-NC-SA license. 
creativity, and action so that many of them switch professions to run online businesses. This period is still ongoing and it is not known how long it will end. Positive self-concept plays an important role in a person's success in adapting to survive because it helps a person to be resilient, patient, courageous, and creative in finding solutions in facing challenges thus opening up greater opportunities to successfully solve the problems.

Keywords: Adaptation; COVID-19; Culture Shock; New Normal; Survival; Tourism Human Resources

\section{Introduction}

At the end of 2019, a virus emerged that quickly spread across the globe. The Coronavirus, then known as Coronavirus disease 2019 (COVID-19), has reportedly claimed the lives of thousands of people in Wuhan, China, in just a few weeks. This virus is considered much more dangerous than its predecessor virus, namely Severe Acute Respiratory Syndrome (SARS), because often, those infected feel nothing until the virus damages their internal organ systems, especially the lungs and heart.

In early March 2020, the Indonesian government officially announced the first cases of COVID-19 infection in Indonesia, the next few days it was stated that cases were increasing rapidly every day. The Indonesian government carefully evaluates the pandemic to prevent the spread of COVID-19 infection (Brahma, 2020; Djalante et al., 2020). Meanwhile, the World Health Organization (WHO) issued health protocols to prevent the outbreak and delay worldwide spread (Homecare24.id, 2020). Information on the spread of infection quickly makes the public panicked, anxious, and fear resulting in a spate of panic buying on face masks, food and necessities, medicines and vitamins, herbs, and other herbal medicines.

The President of Indonesia, Joko Widodo, in a press conference at Bogor Palace (Indonesian Presidential Palace), on March 16, 2020, said that policies for productive activities at home need to be implemented to reduce the spread of COVID-19. "Policies for study from home, work from home, and worship at home need to be intensified to reduce the spread of COVID-19" (Kompas.com, 2020a).

Public health expert and Chief of the Expert Team for the Task Force for the Acceleration of COVID-19 Handling, Prof. drh. Wiku Adisasmito, M.Sc., Ph.D. (a Professor at the Faculty of Public Health, University of Indonesia), said that discipline in implementing social distancing is needed because the virus vaccine is not yet available. The public must follow health protocols to prevent the spread of infection or outbreak (Tribunnews, 2020).

When the social distancing appeal was not able to stop the widespread of the virus, the government has finally taken a policy to implement the LSRR (Large-Scale Social Restriction) in various regencies/municipalities in Indonesia. LSRR is also implemented by suspending flights service starting from 24 May 2020 to 1 June 2020 to prevent the spread of the virus (Suara.com, 2020).

As a result, human movement is severely restricted; activities in all places become very limited even some are forced to close. COVID-19 not only disrupts social and cultural life but economically affects almost all types of businesses. There is no denying that the COVID-19 


\section{Culture Shock, Adaptation, and Self-Concept of Tourism Human Resources in Welcoming the New Normal Era}

pandemic has caused catastrophic effects in the world economy, including the Indonesian economy (McKibbin \& Fernando, 2020).

One of the most heavily affected business sectors is the tourism industry (Riadil, 2020), whereas previously the tourism industry was estimated to generate the largest foreign exchange in Indonesia (iNews.id, 2019).

The COVID-19 pandemic has a huge impact on the tourism industry sector, which is currently the second-largest contributor to foreign exchange in Indonesia (iNews.id, 2019). The suspension of flight services and the closure of various tourist destinations caused the hotel and restaurant business to collapse in all regions in Indonesia, although the earliest ones were in Bali, Yogyakarta, Jakarta, and West Java.

Chairman of the Indonesian Hotel and Restaurant Association (Perhimpunan Hotel dan Restoran Indonesia or PHRI), Hariyadi B. Sukamdani, explained that the occupancy rate of hotels in Jakarta is only $30 \%$. This means that $70 \%$ of hotel rooms are unfilled or empty. In its development until the end of April 2020, more than 2,000 hotels in Indonesia were no longer operating as occupancy rates continue to decline to $10 \%$, making it no longer adequate to run hotel operations (Medcom.id, 2020).

The difficult circumstances and limited space for movement have encouraged the community and Tourism Human Resources to innovate. New business ideas by utilizing technology, including online courier services, online culinary product sales, and virtual tours initiated by many travel agencies that are currently unable to operate normally. Hotels in several developed countries have also used robot services in the form of Bellboy robots, Room Service robots, and Runner robots. Although initially this robot service aimed at utilizing technology and efficiency of labor, it can also be used to minimize direct physical contact with hotel guests.

The consequence of the implementation of social distancing and physical distancing is the capacity limitation, longer queuing distances, less capacity, and so on. People's life, psychologically and socio-economically, is changing as an adaptation to this pandemic. Young adults are the age group that is almost ready to change their lifestyle and daily habits and are willing to adopt health protocols to keep life as safe and comfortable as possible in these pandemic conditions (Buzzi et al., 2020). Young adults better understand the development of technology which plays an important role in every aspect of life during this pandemic, apart from that young adults are indeed at a creative and spirited stage in their lives.

Until now, there is still a lot of uncertainty about the end of the COVID-19 pandemic, some say the virus will naturally break down even though it takes a relatively long time. However, Prof. Drs. Sutiman Bambang Sumitro, SU, D.Sc, a Professor of Biology at Universitas Brawijaya said that Covid-19 will continue to exist for all time, as is HIV, dengue fever, tuberculosis, and others. Thus, public health and immunity must be maintained (Hukum Ekonomi Islam Universitas Darussalam Gontor, 2020).

The results of research conducted by Thevarajan et al, (2020), published in Nature Medicine, "Breadth of concomitant immune responses before patient recovery: a case report of non-severe COVID-19", states that a healthy immune system can beat SARS-CoV-2 (Putra, 2020).

Dr. Michael Ryan, Executive Director, WHO Health Emergencies Programme stated that COVID-19 will never go away, which means that the virus will remain in human life even though the virus vaccine has been found. To stop this pandemic, increasing body immunity and implementing health protocols in carrying out daily activities is very important to do (Kompas, 2020b). 
As this uncertainty continues, we must increase awareness of all the worst possibilities and hope this pandemic ends. However, what if the COVID-19 pandemic ends and humans must begin to adapt to continue living in these conditions? Will there be a second culture shock after the first culture shock at the beginning of the COVID-19 pandemic? Is there anything that can be done to live a normal life back to the way it was? This research aims to discuss the understanding of cultural shock as the reality of social life, and the ability of Tourism Human Resources to adapt to different environments, as well as the influence of positive self-concepts on survival abilities.

\section{Literature Review}

\subsection{Culture Shock}

In the context of intercultural communication, namely the delivery of messages between those from different cultures (Samovar et al., 2014), culture shock often occurs even though the severity differs from one person to another (Sekeon, 2013). This indicates that humans experience shocks, discomforts, and certain negative feelings when it comes to a culture that is new to it.

The term "Culture Shock" was first introduced by anthropologist Kalervo Oberg in 1960 to describe the profound negative responses related to depression, frustration, and disorientation experienced by someone living in a new cultural environment (Dayakisni \& Yuniardi, 2008). This term expresses a lack of direction, not knowing what to do, or how to do things in a new environment, and not knowing what is appropriate or inappropriate. Culture shocks and the process of adapts in dealing with it are illustrated in the following curve:

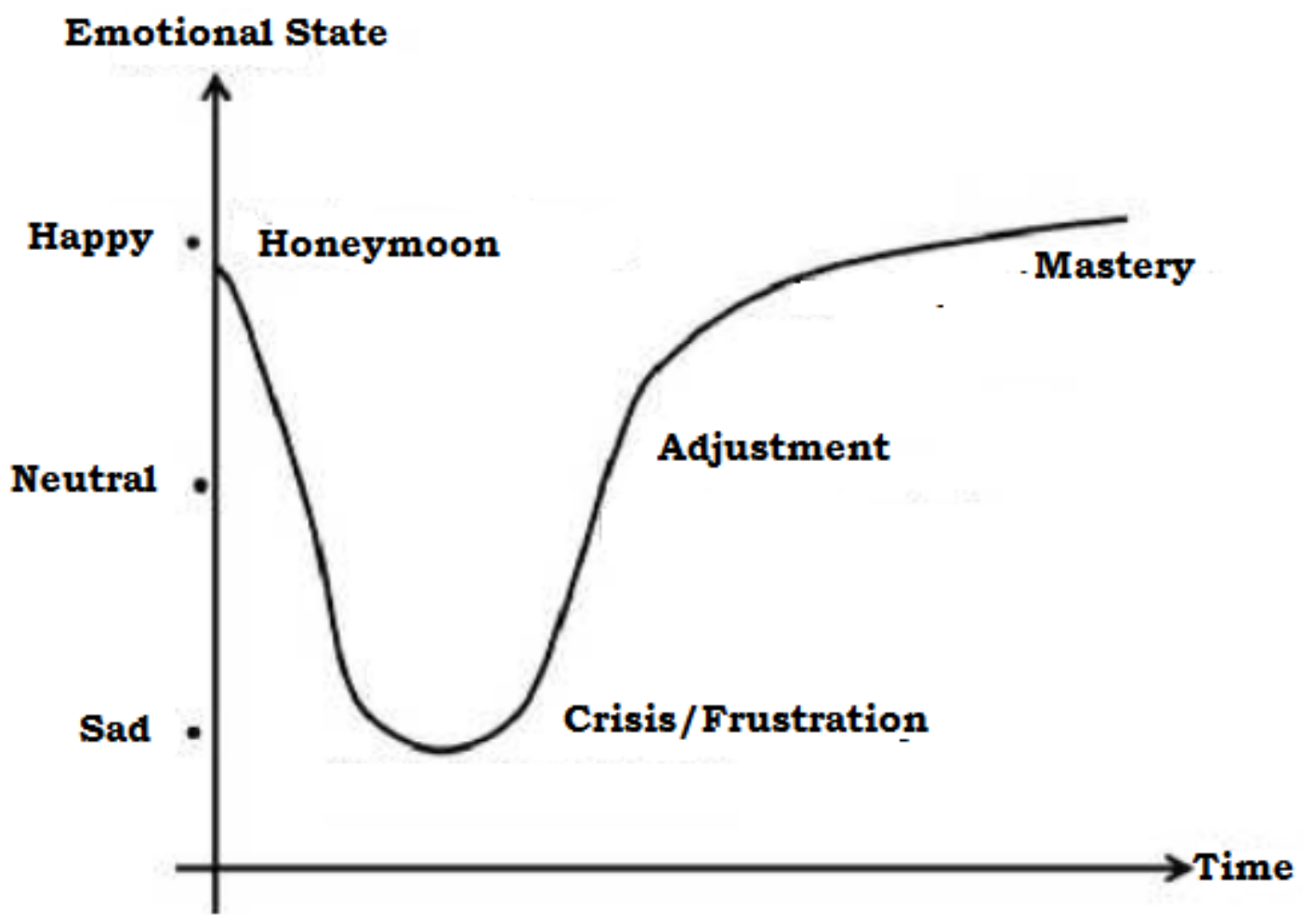

Figure 1. Stages of Culture Shock

Source: Samovar et al, (2017), as cited in Khoirunnisa \& Soemantri (2019) 


\section{Culture Shock, Adaptation, and Self-Concept of Tourism Human Resources in Welcoming the New Normal Era}

There are four stages or periods of culture shock which are described in the form of a Ucurve in Figure 1. First, the Honeymoon period: a period that contains excitement, a sense of hope, and euphoria as a person's anticipation before entering a new culture. Second, Crisis/Frustration period: a period of crisis that a person experiences due to a new environment and initial problems that have started to occur. Third, the Adjustment period: the phase where a person begins to understand their new culture. Fourth, the Mastery period: the phase when a person has understood the key elements of the new culture being experienced (Khoirunnisa \& Soemantri, 2019).

Several factors influence the occurrence of culture shock which consists of interpersonal factors which include skills (communication skills), previous experience (in a cross-cultural context), personal character (independence or tolerance), and access to resources. Physical factors also influence such as appearance, age, health, and socializing ability (Parrillo, 2011). Reactions to cultural shocks vary from a person and others, from complex reactions to mild reactions. Likewise, with the impact of cultural shocks on a person, some appear quickly but some are relatively slow (Andani, 2018).

\subsection{Adaptation}

Adaptation is defined as a self-adjustment at the same time as a form of self-change according to environmental conditions (Gerungan, 2010). Humans are constantly adapting to their physical, psychological, and spiritual environment. In the context of intercultural communication, adaptation can be divided into two categories, namely cultural adaptation and social adaptation. Cultural adaptation is the process of changing elements in a person's culture which causes these elements to function better for the people around them and themselves. Meanwhile, social adaptation is the process of change carried out by a person in a new social group so that the person can better interact in that environment.

Individuals who are classified as being able to make positive self-adjustment are characterized by not showing excessive emotional tension, not showing wrong defense mechanisms, showing no personal frustration, having rational consideration in self-direction, being able to learn from experience, and being realistic and objective (Fatimah, 2010). Individuals can be categorized as adapting well when able to perform mature, efficient, satisfying, and healthy responses (Schneiders, 1984, as cited in Ali \& Asrori, 2015).

Adaptation is an individual's effort to achieve self-equality and the environment. Individuals will be able to make a positive adaptation to different situations if they try to overcome these differences, not avoid, or leave (Siregar \& Kustanti, 2018).

\subsection{Self-Concept}

The communication psychology perspective aims to describe, predict, and control mental and behavioral events in communication as stated by Khairani (2015) as cited in Putri (2019). Likewise, looking at responses that occurred in the past can predict future responses. Thus, it can be an insight in discussing the changing mental attitude of Tourism Human Resources to the situation that occurred during the COVID-19 pandemic and welcoming the new normal era.

The results of research conducted by Sunnah (2014) showed that self-concept has a strong and positive relationship with problem-solving abilities. This means that the more positive a person's self-concept, the higher ability to solve problems. Based on these thoughts, a person's self-concept can be relied upon in solving the problem of the culture shock of Tourism HR.

Self-concept is how someone assesses himself or herself, sees himself or herself, and becomes the self that others want, which someone wants or does not want, it must be fulfilled.

Copyright (C 2020. Owned by Author(s), published by Society. This is an open-access article under the CC-BY-NC-SA license. 


\section{Culture Shock, Adaptation, and Self-Concept of Tourism Human Resources in Welcoming the New Normal Era}

What kind of self which wanted by himself or herself, and the self which is wanted by the environment, as wanted by parents, siblings, and friends. Another example, someone wants himself or herself to be successful, smart, rich, or great. Although basically everyone wants to be a good person, in reality not everyone is good.

Self-concept is a physical, social, and psychological perception of himself or herself, which is obtained based on someone's experiences and interactions with others (Brooks as cited in Rakhmat, 2018). Self-concept is someone's views, assessments, and feelings about himself or herself. This self-concept can be psychological, social, and physical. Self-concept is everything that is thought and felt as well as a series of beliefs and behaviors that are believed about himself or herself (Taylor as cited in Rakhmat, 2018)

There are times when people say that someone is "un-self-aware", which means that someone does not recognize himself or herself when in fact knowing himself or herself is good, especially if then it can shape himself or herself to be positive. There are two kinds of selfconcept, namely positive self-concept and negative self-concept (Brooks as cited in Rakhmat, 2018). The characteristics of a person who has a positive self-concept are having confidence in their ability to solve problems, feeling equal to others, receiving praise without shame, and realizing that everyone has feelings, wishes, and behaviors that the community does not necessarily agree with, also a person who can improve and develop himself or herself. Meanwhile, people who have a negative self-concept are characterized by sensitivity to criticism, responsive to praise, tend to feel disliked by others, not confident, and pessimistic about competition. Those who have a positive self-concept try to identify themselves well will be more confident in their potential, and if there is a weakness in them, they will introspect themselves and turn into a better person to make them more developed. People who have a positive self-concept are generally willing to open up and accept new experiences and ideas. Strong self-confidence, which is part of a positive self-concept, is very helpful in the process of individuals adapting to new environments and circumstances (Irfan \& Suprapti, 2014).

\section{Research Methodology}

This research used a qualitative research method with a case study approach. Gunawan (2013, p. 143) described qualitative research as a type of research whose findings are not obtained through statistical procedures or other forms of calculation. Although, this research involved statistical data and surveys from the Ministry of Tourism and Creative Economy/Tourism and Creative Economy Agency of the Republic of Indonesia regarding tourism businesses during the pandemic.

Research with a case study approach according to Prihatsanti et al, (2018) is widely used in social sciences, to provide an understanding of something that attracts attention, phenomenal, social processes that occur, as well as concrete events. A case study is expected to capture the complexity of a case such as the impact of the COVID-19 pandemic on the tourism industry and Tourism Human Resources.

This is descriptive research, which describes information data based on facts obtained in the field to describe existing phenomena. Nazir (2003) stated the steps are as follows: 1) Identifying the problems; 2) Formulate the problems clearly; 3) Determine the objectives and benefits of the research; 4) Conduct literature study related to the problem; 5) Determine the framework and research questions and/or research hypotheses; 6) Designing research methods; 7) Collect, organize, and analyze relevant data; and 8) Preparing research reports.

The qualitative descriptive method in this research is used to develop theories built from data obtained through literature study, interviews, observation, and documentation. Interviews

Copyright (C 2020. Owned by Author(s), published by Society. This is an open-access article under the CC-BY-NC-SA license. https://doi.org/10.33019/society.v8i2.200

408 


\section{Culture Shock, Adaptation, and Self-Concept of Tourism Human Resources in Welcoming the New Normal Era}

were conducted with Tourism Human Resources consisting of hotel general managers, managers, hotel operational officers, hotel owners, and affected tourism business employees. This research was conducted to obtain an in-depth overview of the culture shock, adaptation, and survival of Tourism Human Resources in welcoming the new normal era.

There were 14 informants interviewed as primary data consisting of 2 General Managers, 4 Heads of Departments, 6 Operational Officers in various hotels in Bandung and Jakarta, and 2 Tour Operators. Besides, collective interviews were also conducted through the WhatsApp group "Housekeepers Jabar" which consists of more than 200 members as secondary data. The basis of informant selection is to obtain comprehensive information at the top managerial level, intermediate, and operational officers.

\section{Results and Discussion}

\subsection{Culture Shock as a Social Reality}

The reality of people's social life is so disturbed by COVID-19 pandemic. From the state of a normal life, suddenly shocked by the spread of COVID-19 along with the risks and restrictions in its prevention efforts, resulting in people's social experiencing chaos, uncertainty, and fear. Hospital as a place for treatment of disease, it is feared to be a source of disease. There are social restrictions, distance restrictions, changes in the use of certain attributes in interacting with other people. Habits in normal life are restricted, such as touching, shaking hands, and hugging to prevent the spread of COVID-19.

Likewise in tourism activities; very typical social interactions with hospitality are no longer visible because it is covered by facial masks. Facial expressions or attractive facial gestures from officials in various tourism businesses are no longer visible. Facial expressions through the eyes and lips that are called friendly or arrogant are no longer so dominant. Proxemics (semiotics of space) or physical distance ranging from 60 to $75 \mathrm{~cm}$ is getting further away with a minimum of 1.5 meters. The spatial distance that humans use when communicating with others depends on the transactions, the relationships of the individuals interacting, and how they feel and what they are going to do.

Hall as cited in Rakhmat (2018) describes human relations based on four types of distance, namely 1) intimate distance, 2) personal distance, 3) social distance, and 4) public distance. In tourism services, the determination of the distance varies greatly, in the front office of the hotel, for example, it is limited by a fixed distance with the hotel clerk's counter desk which is approximately $75 \mathrm{~cm}$.

Unlike the distance specified in various restaurants, the distance between hotel clerks when serving hotel guests is different from the distance to deliver food which is almost not far away. Certainly, the orientation of officers in carrying out their work is fluency in service by considering politeness. The distance between flight attendants and passengers is also similar, when delivering food, both in assisting passengers in accessing passenger facilities, to helping sick passengers with very close distances. In fact, in a pandemic situation, distance is not only influential socially but also economically, where the area of space becomes more limited due to limited carrying capacities, such as lift capacity, restaurant capacity, flight capacity, and ballroom capacity. Meanwhile, the operational level of hotels, flights, and other transportation are still low. Keeping the area and personal clean is very important, even the most important thing at this time. Hand washing regulations for guests as well as hotel and restaurant staff are very important to implement.

The keynote speaker, Drs. Parlindungan Marpaung, P.Si., a motivator, inspiring trainer, and book author, at a webinar via Zoom Conference with the topic “WOW SERVICE IN CRISIS",

Copyright (C 2020. Owned by Author(s), published by Society. This is an open-access article under the CC-BY-NC-SA license. 


\section{Culture Shock, Adaptation, and Self-Concept of Tourism Human Resources in Welcoming the New Normal Era}

organized by PT Fortuna Indonesia, on Friday, May 15, 2020, said that leading restaurant management provides product quality assurance and employee personal hygiene, health protocols are updated and adjusted to the current crisis conditions. It was also said that employees who commit violations such as not washing their hands when entering and leaving the kitchen will be penalized in the form of warnings to salary deductions. Direct communication at the reception desk has now been installed glass barriers. Services for guest arrivals are equipped with thermo gun, hand sanitizer, and gloves (PT Fortuna Indonesia, 2020a).

Physical attractiveness is hindered by other attributes; friendly relationships are disguised by distance, should not touch, and are covered by gloves and masks. Guests feel increasingly insecure about this situation, as well as the hotel clerks. There are many concerns and even prejudice between people, whether someone is free of the virus, carrier, or is even positively infected with COVID-19.

Human interaction in various interests and activities makes human movement so dynamic. It could be someone doing business activities in several cities and even several countries in a day. It could be that someone in Indonesia in the morning, in Singapore during the day, and at night already in Japan. This is a picture of the reality of global human social life, but a picture of global interactions like this does not always have a positive impact, it can also have negative impacts such as being a carrier for the spread of COVID-19.

The results of interviews with several hotel general managers, hospitality practitioners, and professional associations in the tourism sector stated that they are experiencing this adaptation process, and it is not only limited to cultural adaptation and social adaptation but also economic adaptation, where suddenly they no longer earn an income due to conditions hotels and other tourism businesses affected by COVID-19 raises the following conditions:

1) Unpaid leave;

2) Terminating daily workers;

3) Implement a system of rotating working hours and cutting wages by an average of $50 \%$ and some even reaching $75 \%$;

4) Lack of service charge;

5) Completely lost income for several closed hotels.

Many Tourism Human Resources have lost their jobs and income due to the impact of COVID-19 pandemic. The changing reality of people's social life as a result of the COVID-19 outbreak which is so devastating has affected their minds and feelings into fear and worry, making them depressed. The impact of the pandemic is so big on tourism. Tourism businesses, Tourism Human Resources, and tourists themselves are affected and cause paralysis of the tourism business. Tourism Human Resources have the potential to lose their jobs, changes in work culture, especially their survival, which creates uncertainty and causes them to experience culture shock.

The reactions that may occur for people who experience culture shock are as follows:

1) Antagonistic or hostile to the new environment. Almost everyone finds it difficult to accept unpleasant situations that cut off kinship, brotherhood, friendship, and work relationships. The breakup of social relations creates a feeling of hatred or hostility towards this situation, especially for Indonesian society, which is a collective society, which is a high social relationship between members of society according to a system of traditions and shared identities. In general, Indonesian people like to gather, so there is a slogan "mangan ora mangan, sing penting kumpul", meaning that even though you haven't eaten, the most 


\section{Culture Shock, Adaptation, and Self-Concept of Tourism Human Resources in Welcoming the New Normal Era}

important thing is to stay together. This collective culture has collapsed because of the LSRR (Large Scale Social Restriction), people feel that part of their world is missing, as is what the Tourism Human Resources feel.

2) Feeling lost direction. With the dismissal of the Tourism HR, they feel lost their way because their work routine has been cut off which causes uncertainty day after day.

3) Sense of rejection. The appearance of disappointment, opposition to this situation is a picture of rejection of the situation that occurred. Tourism Human Resources who are active or inactive are certainly feeling the rejection of this situation but this is a reality that occurs and must be faced.

4) Stomach/gastric disorders and headaches. Not everyone who experiences culture shock will experience stomach/gastric disorders, but headaches/dizziness is almost felt by everyone.

5) Longing for friends and relatives. Employees yearn to meet, interact, and do activities together, and this is a reflection that humans are social beings who need other people.

6) Feeling lost in status. In special conditions, some feel lost their status, because the previous culture has changed, for example, a new health protocol, a new appearance, a new social distance, so they feel lost or experienced a change in identity or status.

7) Withdrawal. People who experience culture shock may also experience withdrawal from their new environment, feeling unsuitable or inadequate called withdrawal.

Informants who are members of professional associations, in the WhatsApp group "Housekeepers Jabar", stated that in general during the first month of the COVID-19 pandemic they experienced negative feelings such as anger, disappointment, worry, fear of losing their jobs, and longing for relatives and friends but could not meet, dizzy, and so on. Almost all the news about the tourism business in the next 2 months used a lot of negative words such as falling, being paralyzed, unable to survive, bankruptcy, and the like, of course, these words describe a negative situation that is happening and is being experienced.

\subsection{Adapting to Change}

COVID-19, which is changing the order in the tourism sector, likes it or not, this condition requires individuals to make adaptations to survive.

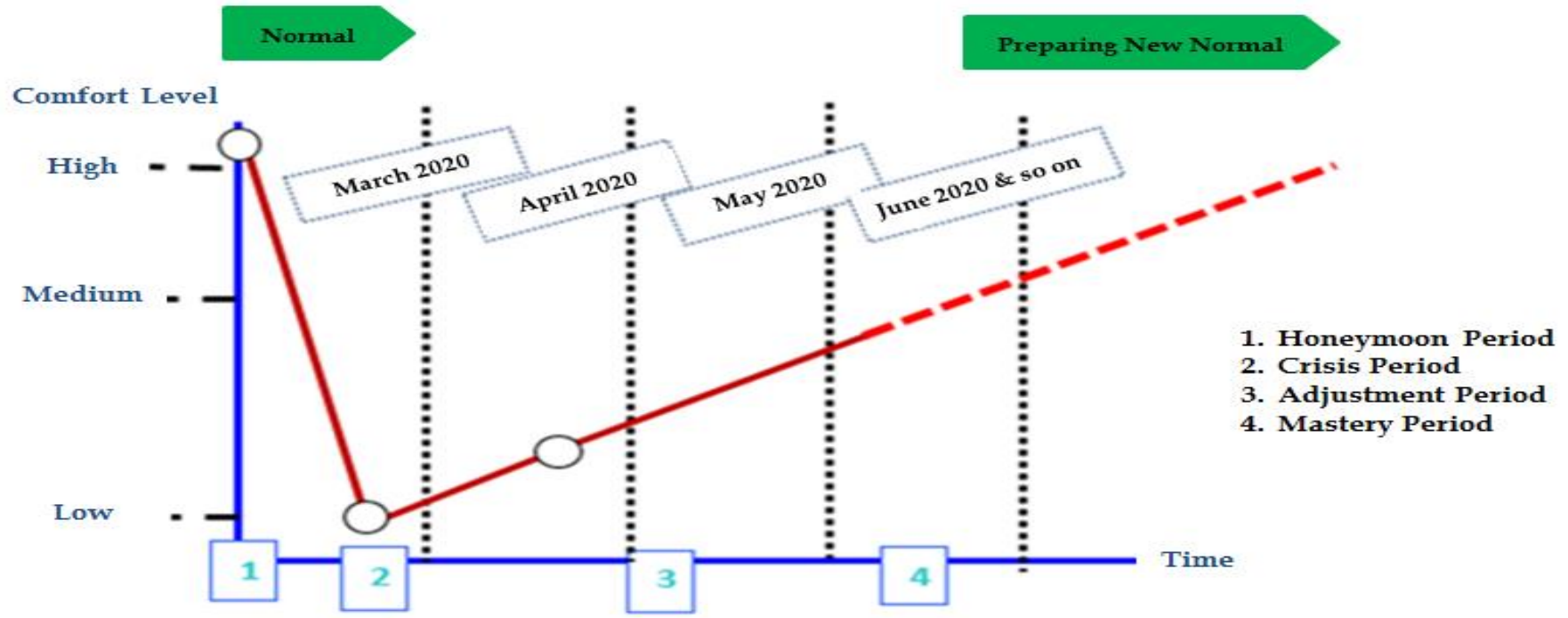

Figure 2. The adaptation process of Tourism HR during the COVID-19 pandemic Source: Primary Data (2020)

Copyright (C 2020. Owned by Author(s), published by Society. This is an open-access article under the CC-BY-NC-SA license. 


\section{Culture Shock, Adaptation, and Self-Concept of Tourism Human Resources in Welcoming the New Normal Era}

The stages of Tourism Human Resources adaptation in cultural change are as follows:

1) The honeymoon period or initial euphoria stage is the initial period of entering a new environment where someone enters a happy period and admires their new environment. However, in this case, this stage is a period of euphoria in a normal, comfortable, and stable situation where tourism in Indonesia is in a stable condition, tourism businesses are running normally, individuals in the tourism community work in normal situations, as well as tourist behavior.

2) The crisis period or frustration stage is the emergence of unpleasant feelings in a new situation as a result of mass media coverage about COVID-19 which is very scary. Besides, difficulties in adapting to the impact of the outbreak, such as social restrictions, resulted in a drastic decline in travel dynamics, causing a decline in the tourism business. This condition has a direct impact on employees. Employees are forced to temporarily be laid off, unpaid leave, work from home, and even dismiss employees. Besides, there was a change in Standard Operating Procedure (SOP) because it must be oriented towards preventing the spread of COVID-19 by providing many facilities such as a thermo gun, hand sanitizer, hand wash, face shield, and masks. There has been a change in the principles of the tourism business from "hospitality and grooming first" to "safety and health first". The overall discomfort caused by the COVID-19 pandemic is called culture shock.

3) The adjustment period is a period where Tourism Human Resources enter a period of awareness where they begin to open up and understand that they have entered a new environment and face the problems they experience with a positive attitude. This situation makes many people change, there is a spirit to rise from a crisis and adjust to their new environment. Many online and free tourism business training is conducted everywhere which aims to motivate individuals in the tourism community to deal with this changing situation. There are solutions for travel businesses that are already offline becoming online, for example, the rise of virtual tours as a solution to overcome these social restrictions. Developed countries such as Japan and Singapore are creating robots in hotel services to reduce direct contact with guests, although this could result in a reduction in the number of employees. Individuals in the tourism community are starting to create new products in almost all types of tourism businesses. This includes safety and health-oriented selfprotection innovations for employees and guests. The LSSR (Large-Scale Social Restrictions) relaxation plans in several areas also an overview that there will be better conditions after the COVID-19 pandemic. This is a picture of the rise of Indonesian tourism.

4) Biculturalism period/Mastery period is a period of full adaptation experienced by a person, although there may still be self-tension, individuals in the tourism community try to control their feelings, which over time the tension will disappear. Tourism entrepreneurs, individuals in the tourism community as well as tourists who were previously uncomfortable accepting changes caused by health protocols in places such as hotels, transportation facilities, airports, and tourist attractions that impose physical distance, notouch, wear masks and meet with limited time as well as robot services. However, the change in mindset from the normal period which prioritizes hospitality to the new normal period which prioritizes safety and health makes all parties in tourism lead to full adaptation. They not only understand and accept habits, values, and other cultural elements, but begin to enjoy, imitate, and even try to make it a new life experience and selfcontrol in uncomfortable times.

Copyright (C) 2020. Owned by Author(s), published by Society. This is an open-access article under the CC-BY-NC-SA license. 


\section{Culture Shock, Adaptation, and Self-Concept of Tourism Human Resources in Welcoming the New Normal Era}

There are three aspects adapted during this adaptation period, namely 1) cultural adaptation, for example, work culture, organizational culture, and community culture have changed; 2) social adaptation, many people talk less and reduce contact, no longer visit each other between parents and children and relatives; 3) economic adaptation, from which everything originally went normally to an uncertain direction.

Khoirunnisa \& Soemantri (2019) described the adaptation process with a U curve that connects time and comfort, where changes in comfort are not too drastic and take a relatively long time. Slightly different from that description, the current individual adaptation process in the tourism community describes a comfort that suddenly drops dramatically and only in a short time. Drastic changes occurred in March 2020 after the implementation of the LSSR (Large-Scale Social Restrictions) policy where there were no more tourist trips and hotel activities, which results in the paralysis of hotel operations and travel businesses. It is depicted by a line that goes down sharply and farther down. Likewise, the awareness of Tourism Human Resources to rise from an uncomfortable situation which is described by a line with a slope that is not asymmetrical as the decrease in their comfort.

Awareness to rise to survive is not easy because it is limited by the conditions of the ongoing pandemic. Concern about the transmission of the virus is still high, causing a lack of flexibility in making changes to new conditions. In this situation, they have only reached 3 periods of the adaptation process because the process is still ongoing and still in the awareness period and fighting towards full adaptation. So, if it is drawn into a curve, it will be shaped like an asymmetric $\mathrm{V}$, with the following details:

1) At the end of March 2020, the comfort of individuals in the tourism community showed a decline to its lowest point because the government's call for social distancing and physical distancing was considered ineffective in overcoming the spread of COVID-19. The government then decided to implement the LSSR, in which the mobility of citizens was severely restricted and even stopped. At this stage, almost all types of tourism businesses are affected, even many have to stop operating, starting from airlines, travel agencies, hotels, culinary businesses, and so on.

2) From the end of March 2020 to the end of April 2020, individuals experience a period of crisis or culture shock in which new rules, procedures, and habits are considered a condition that causes psychological distress even though at this period the pandemic has been accepted as a reality. The comfort level is not as low as the previous period.

3) From the end of April 2020 to June 2020, individuals in the tourism community who were affected by the COVID-19 pandemic conditions have started to wake up and be aware and try to struggle to face and survive with reality. Some of those who lost their jobs began to look and build businesses that they can do in times of crisis. This period is ongoing and it takes a long time for all these new normal conditions to be considered completely normal and a part of individual life in the tourism community.

\subsection{Self-Concept and Survival}

Related to an individual's success in survival, survival effort is the ability to fight for survival in uncomfortable or threatened conditions or circumstances. Similarly, the impact of the COVID-19 pandemic crisis is heavily influenced by positive self-concept. Therefore, tourism personnel must build positive self-concepts to be moved to improve their ability to solve problems, be able to develop themselves, and act to do something that produces something productive and improves its competence and is always passionate in self-development. This positive self-concept will lead them to the mastery period, where the individual has fully

Copyright (C 2020. Owned by Author(s), published by Society. This is an open-access article under the CC-BY-NC-SA license. https://doi.org/10.33019/society.v8i2.200

413 


\section{Culture Shock, Adaptation, and Self-Concept of Tourism Human Resources in Welcoming the New Normal Era}

accepted the cultural changes as a result of the COVID-19 pandemic and has come out of its culture shock period. However, the fact that there are many tourism workers are still depressed or stressed.

In a webinar via Zoom Conference with the topic "Smart Coping Stress" in the context of handling the impact of the COVID-19 pandemic, on Saturday, May 16, 2020, organized by PT Fortuna Indonesia, Drs. Parlindungan Marpaung, P.Si., M.T., M.A., a motivator, inspiring trainer, book author, and also a psychologist, as the first speaker at the webinar, said that unmanaged stress can disturb the psyche (PT Fortuna Indonesia, 2020b). Any discomfort in times of crisis or culture shock experienced by a person must be overcome. There are 6 things to do regarding stress control, namely:

1) Hope. There are still many hopes to be achieved in this life.

2) Master the mind. Use positive thoughts rather than negative feelings.

3) Communicate and stay in touch with relatives and friends, adhere to health protocols, and establish and build social relationships.

4) Do not make excuses or blame, but are moved to do good and meaningful things for others.

5) Turn Stressed into Desserts, turn something unpleasant into something fun, create something useful, and share it with others.

6) Do fun activities such as exercising, listening to music, and things to like.

The second speaker, dr. Indra Muhtadi (health influencer) said that stress is common, humans are not "stress-free", those who are not stressed are numb people, crazy people, and dead people. It is also said that stress can have both positive and negative effects. Constructive stress is referred to as neustress, and stress that is a threat called distress. Stress is part of the reality of human life. What matters is how stress is managed. Therefore it is necessary to adjust to the conditions of change, namely the stages in adaptation theory: "awareness and fighting", trying to continue until the fourth stage, being able to adjust and no longer feel the old cultural changes as a problem because they have been able to overcome them (PT Fortuna Indonesia, 2020b).

The third speaker, Ir. Asep Suhada, an arts activist (expert in traditional angklung music) from Bandung, West Java Province, Indonesia said that the musical signals heard by the ear will be transmitted throughout the body which can reduce tension in the mind. Thus, someone who is tired needs to listen to music to reduce tension. But to achieve this, each individual needs to choose their favorite music (PT. Fortuna Indonesia, 2020b).

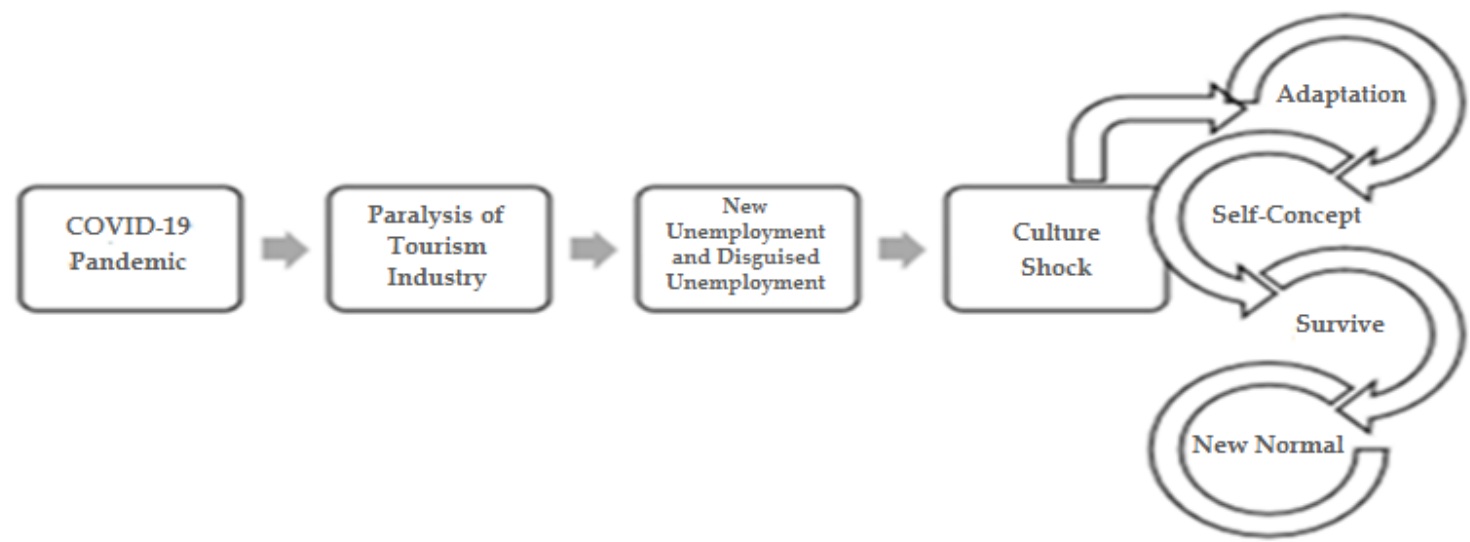

Figure 3. Tourism Human Resources processes in dealing with culture shock due to COVID19 until the new normal period

Source: Primary Data (2020)

Copyright (C) 2020. Owned by Author(s), published by Society. This is an open-access article under the CC-BY-NC-SA license. 


\section{Culture Shock, Adaptation, and Self-Concept of Tourism Human Resources \\ in Welcoming the New Normal Era}

It is clear that the COVID-19 pandemic has triggered sudden changes and made many people, in this case especially the Tourism Human Resources, become momentarily jolted and paralyzed culturally, socially, and economically. This unpreparedness and shock are what is called culture shock which will be able to be faced with an adaptation process which in the process is influenced by a positive self-concept. The more positive the self-concept of the Tourism HR, the easier and faster the adaptation process will be because this concept affects the high ability to survive in facing new conditions.

For Tourism Human Resources, a positive self-concept is an initial capital to be involved in the tourism industry. Tourism Human Resources in their daily lives, doing work activities in the scope of service businesses that prioritize services. To be able to present themselves and provide excellent service that entertains and satisfies consumers, Tourism Human Resources must first provide comfort for themselves. Self-comfort is closely related to how we see ourselves; If we judge ourselves positively, then there is a belief in ourselves that makes us able to present ourselves positively and attractively in front of consumers and vice versa. By looking at this, it is not surprising that Tourism Human Resources who have been hit very hard by the pandemic socially, culturally, especially economically, can immediately overcome culture shock through a relatively short adaptation process and rise from adversity.

\section{Conclusion}

COVID-19 has resulted in paralysis in the tourism industry, which has been followed by an increase in new unemployment and disguised unemployment in Tourism Human Resources. This causes culture shock which is part of the reality of human social life as a result of its interactions with its environment. Likewise, Tourism Human Resources experienced a cultural shock as a result of sudden changes due to the COVID-19 pandemic, thus paralyzing tourism activities that directly impacted employment, income, and the relationship system. As a result, the tourism community becomes depressed, frustrated, and confused about its future. However, the culture shock that occurs can be overcome through a process of adaptation because every individual is naturally gifted with the ability to adapt to his/her environment. To succeed in this adaptation process and survive in the new normal era, a positive self-concept for each individual in society is necessary to face every challenge.

The limitation of this research lies in its relatively short time. The research on this cultural adaptation process was conducted for four months. However, the period of culture shock and adaptation to a new normal period can be thoroughly explained. Since the impact of COVID-19 is still likely to occur for an uncertain time, further research is needed regarding the development of the new normal period and related to changes in Tourism Human Resources behavior.

\section{Acknowledgment}

The authors would like to thank the Indonesian Housekeepers Association (IHKA) of West Java Province and the alumni of Sekolah Tinggi Ilmu Ekonomi Pariwisata YAPARI who work in the tourism industry who have been willing to provide data in this research. Thanks are also given to the inspiring webinar speakers, as well as PT Fortuna Indonesia as the webinar organizer.

\section{Declaration of Conflicting Interests}

The authors have declared no potential conflicts of interest concerning the research, authorship, and/or publication of this article. 


\section{Culture Shock, Adaptation, and Self-Concept of Tourism Human Resources in Welcoming the New Normal Era}

\section{References}

Ali, M., \& Asrori, M. (2015). Psikologi Remaja (Perkembangan Peserta Didik). Jakarta, Indonesia: PT. Bumi Aksara.

Andani, D. (2018). Penyesuaian Diri Mahasiswa Terhadap Culture Shock (Studi Deskriptif Kualitatif Penyesuaian Diri Mahasiswa Sulawesi Selatan di Yogyakarta) (Thesis). Universitas Muhammadiyah Surakarta. Retrieved from http:/ / eprints.ums.ac.id/57900/

Brahma, B. (2020). Oncologists and COVID-19 in Indonesia: What can we learn and must do? Indonesian Journal of Cancer, 14(1), 1-2. https:/ / doi.org/10.33371/ijoc.v14i1.728

Buzzi, C., Tucci, M., Ciprandi, R., Brambilla, I., Caimmi, S., Ciprandi, G., \& Marseglia, G. L. (2020). The psycho-social effects of COVID-19 on Italian adolescents' attitudes and behaviors. Italian Journal of Pediatrics, 46(1). https:/ / doi.org/10.1186/s13052-020-00833-4

Dayakisni, T., \& Yuniardi, S. (2004). Psikologi Lintas Budaya. Malang, Indonesia: UMM Press.

Djalante, R., Lassa, J., Setiamarga, D., Sudjatma, A., Indrawan, M., Haryanto, B., ... Warsilah, H. (2020). Review and analysis of current responses to COVID-19 in Indonesia: Period of January to March 2020. Progress in Disaster Science, 6, 100091. https:/ / doi.org/10.1016/j.pdisas.2020.100091

Fatimah, E. (2010). Psikologi Perkembangan (Perkembangan Peserta Didik). Bandung, Indonesia: Pustaka Setia.

Gerungan, W. A. (2010). Psikologi Sosial. Bandung, Indonesia: Refika Aditama.

Gunawan, I. (2013). Metode Penelitian Kualitatif. Jakarta, Indonesia: PT. Bumi Aksara.

Homecare24.id. (2020, July 20). Ini Dia Protokol Kesehatan Covid-19 yang Baru! Akibat Penularan Melalui Udara. Retrieved from https://medium.com/@homecare24.blog/inidia-protokol-kesehatan-covid-19-yang-baru-akibat-penularan-melalui-udara-733ab2a2fca

Hukum Ekonomi Islam Universitas Darussalam Gontor. (2020, May 17). Bagaimana Cara Hidup Damai dengan Covid-19 (Corona Virus) - Islamic Economics of Law Department. Retrieved from http://hes.unida.gontor.ac.id/bagaimana-cara-hidup-damai-dengancovid-19-corona-virus/

Irfan, M., \& Suprapti, V. (2014). Hubungan self-efficacy dengan penyesuaian diri terhadap perguruan tinggi pada mahasiswa baru Fakultas Psikologi Universitas Airlangga. Jurnal Psikologi Pendidikan dan Perkembangan, 3(3), 172-178. Retrieved from http:/ / www.journal.unair.ac.id/download-fullpapers-jppp47cf73fd802full.pdf

iNews.id. (2019, September 9). Sektor Utama Ekonomi Nasional, Pariwisata Akan Menjadi Penghasil Devisa Terbesar. Retrieved from https:/ / www.inews.id/travel/destinasi/sektor-utama-ekonomi-nasional-pariwisataakan-menjadi-penghasil-devisa-terbesar

Khoirunnisa, Y., \& Soemantri, N. P. (2019). Fenomena Gegar Budaya pada Warga Negara Perancis yang Bekerja di Jakarta. Jurnal Antropologi: Isu-Isu Sosial Budaya, 21(2), 254-261. https:/ / doi.org/10.25077/jantro.v21.n2.p254-261.2019

Kompas.com. (2020a, March 16). Jokowi: Kerja dari Rumah, Belajar dari Rumah, Ibadah di Rumah Perlu Digencarkan. Retrieved from https:/ / nasional.kompas.com/read/2020/03/16/15454571/jokowi-kerja-dari-rumahbelajar-dari-rumah-ibadah-di-rumah-perlu-digencarkan?

Kompas.com. (2020b, May 14). WHO Peringatkan, Virus Corona Tidak Akan Hilang Meski Ada Vaksin.

https:/ / www.kompas.com/sains/read/2020/05/14/123200923/who-peringatkan-viruscorona-tidak-akan-hilang-meski-ada-vaksin? 


\section{Culture Shock, Adaptation, and Self-Concept of Tourism Human Resources in Welcoming the New Normal Era}

McKibbin, W., \& Fernando, R. (2020). The economic impact of COVID-19. In R. Baldwin \& B. Weder di Mauro (Eds.), Economics in the Time of COVID-19 (pp. 45-52). Retrieved from https:/ / cepr.org/sites/default/files/news/COVID-19.pdf

Medcom.id. (2020, March 12). PHRI: Imbas Korona, Okupansi Hotel hanya 30\% - Medcom.id.

Retrieved from https://m.medcom.id/ekonomi/bisnis/4bamrzZb-phri-imbas-koronaokupansi-hotel-hanya-30

Nazir, M. (2003). Metode Penelitian. Jakarta, Indonesia: Ghalia Indonesia.

Parrillo, V. N. (2011). Strangers to these shores: Race and ethnic relations in the United States (10th ed.). Upper Saddle River, NJ, United States: Prentice-Hall.

Prihatsanti, U., Suryanto, S., \& Hendriani, W. (2018). Menggunakan Studi Kasus sebagai Metode Ilmiah dalam Psikologi. Buletin Psikologi, 26(2), 126-136. https:/ / doi.org/10.22146/ buletinpsikologi.38895

PT Fortuna Indonesia (2020a, May). WOW SERVICE IN CRISIS: Teknik memberikan pelayanan unggul di masa-masa sulit. Presented at Webinar via Zoom Conference: PT Fortuna Indonesia.

PT Fortuna Indonesia (2020b, May). SMART COPING STRESS: Bagaimana kita bisa menangani dan bersahabat dengan stress/kejenuhan/kekhawatiran akibat Pandemic Covid-19 ini?. Presented at Webinar via Zoom Conference: PT Fortuna Indonesia.

Putra, A. (2020, September 20). 8 Cara Menjaga Imun Tubuh untuk Lawan Virus Corona. Retrieved June 12, 2020, from https://www.sehatq.com/artikel/cara-menjaga-imuntetap-sehat-untuk-lawan-virus-corona-covid-19

Putri, N. W. E. (2019). Peran Psikologi Komunikasi dalam Mengatasi Permasalahan Peserta Didik: Studi Kasus Proses Bimbingan Konseling di SMK Kesehatan Widya Dharma Bali. CALATHU: Jurnal Ilmu Komunikasi, 1(1), 52-67. Retrieved from https://journal.uc.ac.id/index.php/calathu/article/view/776

Rakhmat, J. (2018). Psikologi Komunikasi (Revisi ed.). Bandung, Indonesia: PT. Remaja Rosdakarya.

Riadil, I. G. (2020). Tourism Industry Crisis and its Impacts: Investigating the Indonesian Tourism Employees Perspectives' in the Pandemic of COVID-19. Jurnal Kepariwisataan: Destinasi, Hospitalitas Dan Perjalanan, 4(2), 98-108. https:/ / doi.org/10.34013/jk.v4i2.54

Samovar, L. A., Porter, R. E., McDaniel, E. R., \& Roy, C. S. (2014). Intercultural communication: A reader. Boston, United States of America: Cengage Learning.

Sekeon, K. (2013). Komunikasi Antar Budaya Pada Mahasiswa FISIP Unsrat (Studi pada Mahasiswa Angkatan 2011). Acta Diurna Komunikasi, 2(3), 1-14. Retrieved from https:/ / ejournal.unsrat.ac.id/index.php/actadiurnakomunikasi/article/view/1918

Siregar, A. O. A., \& Kustanti, E. R. (2018). Hubungan antara gegar budaya dengan penyesuaian diri pada mahasiswa bersuku minang di universitas Diponegoro. Empati, 7(2), 474-490. Retrieved from https:/ / ejournal3.undip.ac.id/index.php/empati/article/view/21668

Suara.com. (2020, April 23). Indonesia Stop Penerbangan Internasional dan Domestik 24 April 1 Juni. Retrieved June 6, 2020, from https:/ /www.suara.com/news/2020/04/23/201610/indonesia-stop-penerbanganinternasional-dan-domestik-24-mei-1-juni

Sunnah, A. M. (2014). Hubungan Antara Konsep Diri dengan Kemampuan Pemecahan Masalah pada Wirausahawan di Surabaya. Character: Jurnal Penelitian Psikologi, 3(2), 1-5. Retrieved from https:/ /jurnalmahasiswa.unesa.ac.id/index.php/character/article/view/10989

Tribunnews.com. (2020, June 10). Prof Wiku Adisasmito Paparkan Perkembangan Covid-19 di Depan Jokowi. Retrieved June 13, 2020, from

Copyright (C 2020. Owned by Author(s), published by Society. This is an open-access article under the CC-BY-NC-SA license. https://doi.org/10.33019/society.v8i2.200 
https:/ / www.tribunnews.com/metropolitan/2020/06/10/prof-wiku-adisasmitopaparkan-perkembangan-covid-19-di-depan-jokowi

\section{About the Authors}

1. Diana Simanjuntak, obtained her Doctoral degree from Universitas Padjadjaran, Indonesia, in 2010. The author is an Assistant Professor at the Department of Hospitality, Sekolah Tinggi Ilmu Ekonomi Pariwisata YAPARI, Indonesia.

E-Mail: simanjuntak_dn@yahoo.com

2. Rina Fitriana, obtained her Magister degree from Universitas Mercu Buana, Indonesia, in 2017. The author is an Assistant Professor at the Department of Hospitality, Politeknik Sahid, Indonesia.

E-Mail: rinafitriana@polteksahid.ac.id 